\author{
Tove Christiansen \\ Anitha Bruun \\ Yolande E. Knight \\ Peter J. Goadsby \\ Lars Edvinsson
}

\section{Immunoreactivity of NOS, CGRP, PACAP, SP and VIP in the trigeminal nucleus caudalis and in the cervical spinal cord $\mathrm{C} 1$ and $\mathrm{C} 2$ of the cat}

Received: 16 June 2003

Accepted in revised form: 17 July 2003

T. Christiansen • L. Edvinsson ( $($ ) Department of Internal Medicine, Lund University Hospital,

22185 Lund, Sweden

e-mail: lars.edvinsson@med.lu.se

Tel.: +46-46-171484

Fax: +46-46-184792

\section{A. Bruun}

Department of Ophthalmology,

Lund University Hospital,

Lund, Sweden

Y.E. Knight • P.J. Goadsby

Institute of Neurology,

National Hospital for Neurology and

Neurosurgery,

London, United Kingdom

\author{
Abstract The aim of the present \\ study was to map the presence of \\ neurotransmitters and nitric oxid \\ synthase (NOS) in the trigeminal \\ nucleus caudalis and cervical spinal \\ cord of cat. Immunocytochemistry \\ was used to map the presence of \\ neuronal NOS, calcitonin gene-relat- \\ ed peptide (CGRP), pituitary adeny- \\ late cyclase activating peptide \\ (PACAP), substance P (SP) and \\ vasoactive intestinal peptide (VIP). \\ The superior sagittal sinus (SSS) was \\ stimulated electrically for $2 \mathrm{~h}(0.3$ \\ $\mathrm{Hz}, 0.25 \mathrm{~ms}$ duration, $120 \mathrm{~V}$ ) to \\ examine if this would lead to deple- \\ tion of the neurotransmitters. \\ Numerous SP- and CGRP-positive \\ nerve fibers (but no cells) were \\ found in the trigeminal nucleus cau- \\ dalis (TNC) and in Rexed lamina I \\ and $\mathrm{II}^{\circ}$ of the dorsal horn at $\mathrm{C} 1 / \mathrm{C} 2$
}

\begin{abstract}
level of the spinal cord. Moderate amounts of PACAP- and NOS-positive nerve fibers were also seen in these areas while there were only few VIP-positive fibers. There was no observable difference in the amount of immunoreactivity of NOS or the neuropeptides between stimulated and control cats. The stimulation resulted in marked c-fos immunoreactivity in the same regions of the TNC. The bipolar trigeminal neurons project to the TNC and $\mathrm{C} 1 / \mathrm{C} 2$ areas with fibers containing neuropeptides and NOS. Stimulation of the SSS for $2 \mathrm{~h}$ was not sufficient to cause noticeable depletion.
\end{abstract}

Key words Trigeminal nucleus caudalis - Cervical spinal cord $\cdot$ Cat • Neuropeptides $\cdot$ Superior sagittal sinus

\section{Introduction}

Neurovascular headaches, such as migraine and cluster headache, are very disabling, common disorders. Despite much progress in research during recent years both at the therapeutic level with the development of triptans and at the level of the general understanding of the basic mechanisms, there is still much to learn about these disorders [1].

Nociceptive fibers on intracranial vessels such as the superior sagittal sinus (SSS) and the middle meningeal and middle cerebral arteries [2] are central in the understanding of the pathogenesis of neurovascular headache. These vessels are innervated by myelinated $\mathrm{A} \delta$ - and unmyelinated C-fibers from the trigeminal ganglion [3]. The system consists of bipolar neurons with cell bodies that reside in the trigeminal ganglion and project to the dura mater and the SSS as well as the major cerebral arteries at the base of the brain, while the central projection is to the trigeminal nucleus caudalis (TNC) in the caudal medulla oblongata and in the cervical spinal cord at the $\mathrm{C} 1$ and $\mathrm{C} 2$ levels [4]. 
Stimulation of the trigeminal system causes release of the vasodilator neuropeptides substance $\mathrm{P}(\mathrm{SP})$ and calcitonin generelated peptide (CGRP), both in humans and in the cat $[5,6]$, just as a spontaneous migraine attack causes CGRP release in humans [5, 7]. Since electrical stimulation of the SSS results in increased immunohistochemical staining of CGRP in sensory perivascular nerve terminals in the supratentorial cerebral dura mater of rat [8], it is highly likely that the elevation of CGRP in the extracerebral circulation originates in the trigeminovascular system since (i) there is close correlation between cranial venous CGRP and CSF CGRP, (ii) in addition these levels correlate with cerebral vasospasm $[9,10]$ and (iii) that stimulation of the trigeminal ganglion causes elevation of cranial venous CGRP while there is no rise in cubital fossa venous CGRP [6].

Recent research has focused on the cervicomedullary junction and the upper cervical cord. Electrical stimulation of SSS in the cat increased metabolic activity [11] and blood flow [12] in these areas. Central activation of the trigeminovascular pathway is inhibited by dihydroergotamine, probably acting at 5hydroxytryptamine 5-HT $1 \mathrm{~B} / 1 \mathrm{D}$ receptors [13]. Further studies have indicated that triptans, which are more specific $5-\mathrm{HT}_{1 \mathrm{~B} / 1 \mathrm{D}}$ agonists, may act at these neuronal centers in the brainstem and upper cervical cord independently of their vasoconstrictive effect, but only if they can pass the blood brain barrier [14, 15]. In the setting of new therapeutic approaches to vascular headache, it is important to define the role of vasodilators such as CGRP, nitric oxide synthase (NOS), vasoactive intestinal peptide (VIP), SP and pituitary adenylate cyclase activating peptide (PACAP) in the pathogenesis of vascular headache. Therefore, our study was designed to explore the presence of neuropeptides and NOS in the TNC and spinal cord at C1 and C2 levels, and to explore if electrical stimulation of SSS results in depletion of immunoreactive fibers in the cat.

\section{Materials and methods}

Stimulation

Cats were anaesthetized with $\alpha$-chloralose $(60 \mathrm{mg} / \mathrm{kg}$ intraperitoneally) after induction with halothane. The superior sagittal sinus was stimulated with a Grass S88 stimulator driving a stimulus isolation unit (SIU5A; Grass Instruments, Quincy, USA; $150 \mathrm{~V}, 250-\mu \mathrm{s}$ duration) following the previous description [4]. It was stimulated for 2 hours at $0.3 \mathrm{~Hz}, 0.25 \mathrm{~ms}$ duration (train), $120 \mathrm{~V}$.

Perfusion, fixation and freezing

The cats were subsequently perfused transcardially with phosphate buffered saline (PBS), Stefanini solution (2\% formaldehyde and $0.2 \%$ picric acid) and then fixed in Stefanini solution for 12 hours. The brainstem was rinsed and stored in Tyrode solution with $10 \%$ sucrose. For histochemistry it was blocked in $3-\mathrm{cm}$ parts beginning at the level of the obex and ending below spinal segment C3.

The tissue was put in a test tube filled with $50 \mathrm{ml}$ isopenthane that had been stored in dry ice in a $-85^{\circ} \mathrm{C}$ freezer for $20 \mathrm{~min}$. After $10 \mathrm{~s}$, the tissue was removed and stored in a $-85^{\circ} \mathrm{C}$ freezer until it was cut into $10 \mu \mathrm{m}$ slices in a cryostat.

\section{Immunohistochemistry}

The cryostat sections were rinsed for $15 \mathrm{~min}$ in $0.1 \mathrm{M}$ PBS with $0.25 \%$ Triton X-100 pH 7.2 (PBS/T). They were then incubated with stock serum from donkey and PBS/T for $30 \mathrm{~min}$, at room temperature, followed by incubation with primary antibody (Table 1) diluted in PBS/T with $1 \%$ bovine serum albumin (PBS/TB) for $16-24 \mathrm{~h}$ at $+8^{\circ} \mathrm{C}$. The next day the sections were rinsed in $0.1 \mathrm{M} \mathrm{PBS} / \mathrm{T}$ for $15 \mathrm{~min}$ and then incubated with stock serum, biotinylated secondary antibody and $0.1 \mathrm{M} \mathrm{PBS} / \mathrm{T}$ for 30 min at room temperature. The sections were then rinsed in $0.1 \mathrm{M}$ $\mathrm{PBS} / \mathrm{T}$ for $30 \mathrm{~min}$, incubated for $30 \mathrm{~min}$ with avidin biotin peroxidase complex solution $(\mathrm{ABC})$ at room temperature and then rinsed for $30 \mathrm{~min}$. The 3'diaminobenzidine tetrachloride (DAB) staining protocol (Vectastain Elite ABC kit; Kemila/Labora, Stockolm, Sweden) was then applied to the sections. The sections were then rinsed in distilled water, dehydrated and mounted for microscope examination.

Every twelfth section was stained with hematoxylin-eosin for anatomical localization. In addition, some tissue was processed for nuclear protein Fos (c-fos; Oncogene Science, USA) according to a previously published protocol [16].

Table 1 Primary antibodies used

\begin{tabular}{llll}
\hline Antigen & Dilution & Made in & Source \\
\hline Calcitonin gene-related peptide (CGRP) & $1 / 2000$ & Rabbit & Euro-Diagnostica (B 64-1) \\
Pituitary adenylate cyclase activating peptide (PACAP)-38 & $1 / 800$ & Rabbit & Euro-Diagnostica (B 57-1) \\
Substance P (SP) & $1 / 800$ & Rabbit & Euro-Diagnostica (B 45-1) \\
Vasoactive intestinal peptide (VIP) & $1 / 3000$ & Rabbit & Euro-Diagnostica (B 34-1) \\
Nitric oxide synthase (NOS) neuronal, C-terminal & $1 / 1000$ & Rabbit & Euro-Diagnostica (B 220-1) \\
Bovine serum albumin (BSA) & $1 / 1000$ & Bovine & Chemicon \\
\hline
\end{tabular}


Processing

Sections from three control cats and from three stimulated cats were compared at corresponding anatomical levels. Sections from three regions were compared: the caudal medulla oblongata and the $\mathrm{C} 1$ and $\mathrm{C} 2$ levels of the spinal cord.

The sections were photographed under the microscope (Nikon Eclipse E800) and processed with Adobe Photoshop 4.0. The estimation of immunoreactivity of the different neurotransmitters was done visually by an experienced histochemist who was blinded to the experimentation using an arbitrary scale (- no staining; + faint; ++ moderate; +++ rich).

\section{Results}

A rich supply of CGRP-positive nerve fibers but no positive cells was found in the TNC. These CGRP-positive fibers were confined to the dorsal horn where they were densely packed in the Rexed lamina $\mathrm{I} / \mathrm{II}^{\circ}$ (Fig. 1). At the $\mathrm{C} 1$ and $\mathrm{C} 2$ levels, Rexed lamina $\mathrm{I} / \mathrm{II}^{\circ}$ contained numerous CGRP-positive nerve fibers (Figs. 2, 3). Also the tract of Lissauer was CGRP-positive at the C2 level (Fig. 3). There was no difference in staining between stimulated and control cats. In control sections there was no c-fos immunoreactivity. However, after $2 \mathrm{~h}$ of stimulation of the SSS, marked c-fos positivity was seen in the TNC lamina $\mathrm{I} / \mathrm{II}^{\circ}$ (data not shown).

A moderate amount of PACAP-positive fibers was found in the TNC, located in the Rexed lamina $\mathrm{I} / \mathrm{II}^{\circ}$ (Fig. 1). At the $\mathrm{C} 1$ and $\mathrm{C} 2$ levels in the Rexed lamina $\mathrm{I} / \mathrm{II}^{\circ}$ and the tract of Lissauer, a moderate amount of PACAP-positive fibers was observed (Figs. 2, 3). There was no difference between the stimulated and control cats.

There was a rich supply of SP-positive nerve fibers in the TNC, located in the Rexed lamina $\mathrm{I} / \mathrm{II}^{\circ}$ (Fig. 4). At the $\mathrm{C} 1$ and $\mathrm{C} 2$ levels in the Rexed lamina $\mathrm{I} / \mathrm{II}^{\circ}$ and the tract of Lissauer were also richly suppled with SP-positive nerve fibers (Figs. 5, 6). There was no difference between the stimulated and control cats.

There were few VIP-positive nerve fibers in the cat TNC. A weak positive staining was only seen in the Rexed lamina $\mathrm{I} / \mathrm{II}^{\circ}$ (Fig. 4). At the $\mathrm{C} 1$ and $\mathrm{C} 2$ levels in the Rexed lamina $\mathrm{I} / \mathrm{II}^{\circ}$, the amount of VIP-positive nerve fibers was also low (Figs. 5, 6). There was no difference between the stimulated and control cats.

The TNC in the medulla oblongata of the cat contained a moderate supply of NOS-positive fibers (Fig. 4). They constituted a network of delicate varicosed fibers located in Rexed lamina $\mathrm{I} / \mathrm{II}^{\circ}$. At the $\mathrm{C} 1$ as well as $\mathrm{C} 2$ levels of the cat spinal cord, a moderate amount of NOS-positive fibers was found in Rexed lamina $\mathrm{I} / \mathrm{II}^{\circ}$ of the dorsal horn and the tract

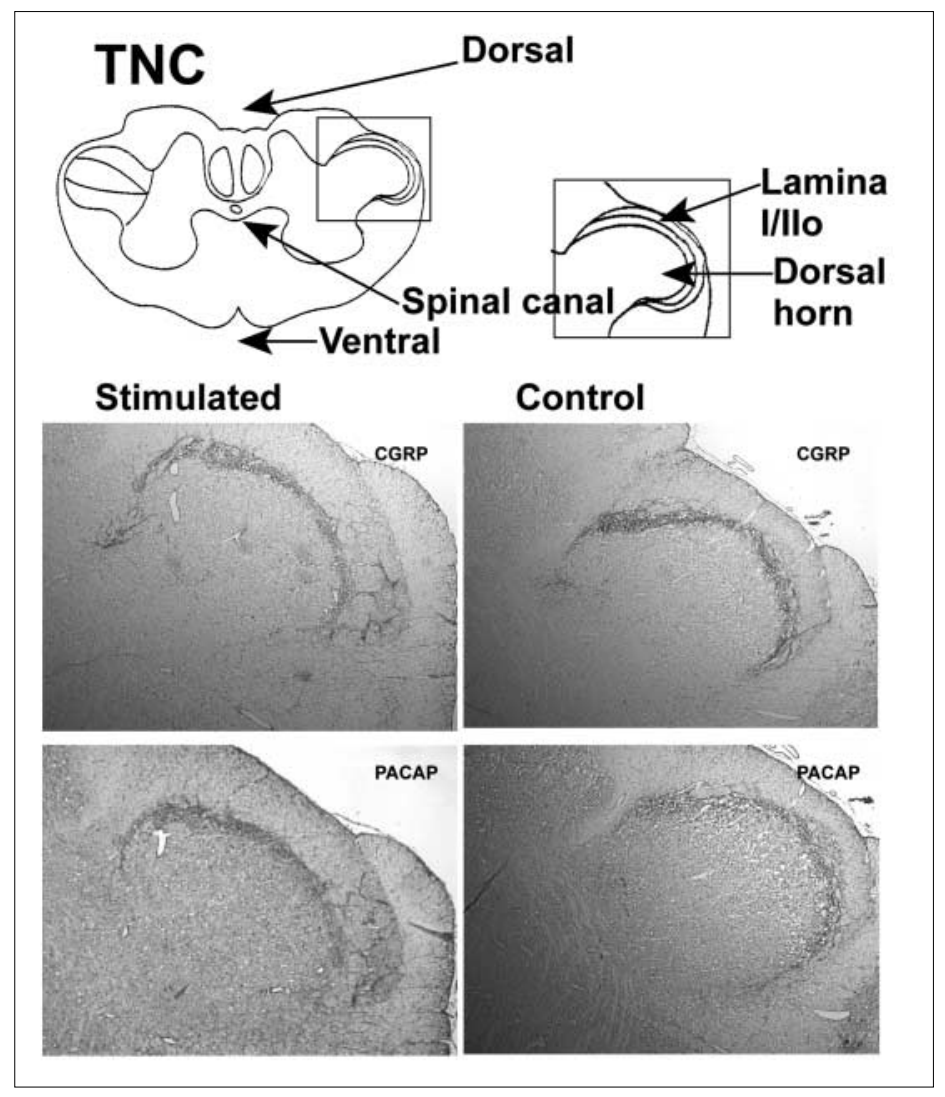

Fig. 1 The trigeminal nucleus caudalis (TNC) in the medulla oblongata in the cat. Organization of the area (top). Immunoreactivity of CGRP (middle) and PACAP (bottom) 


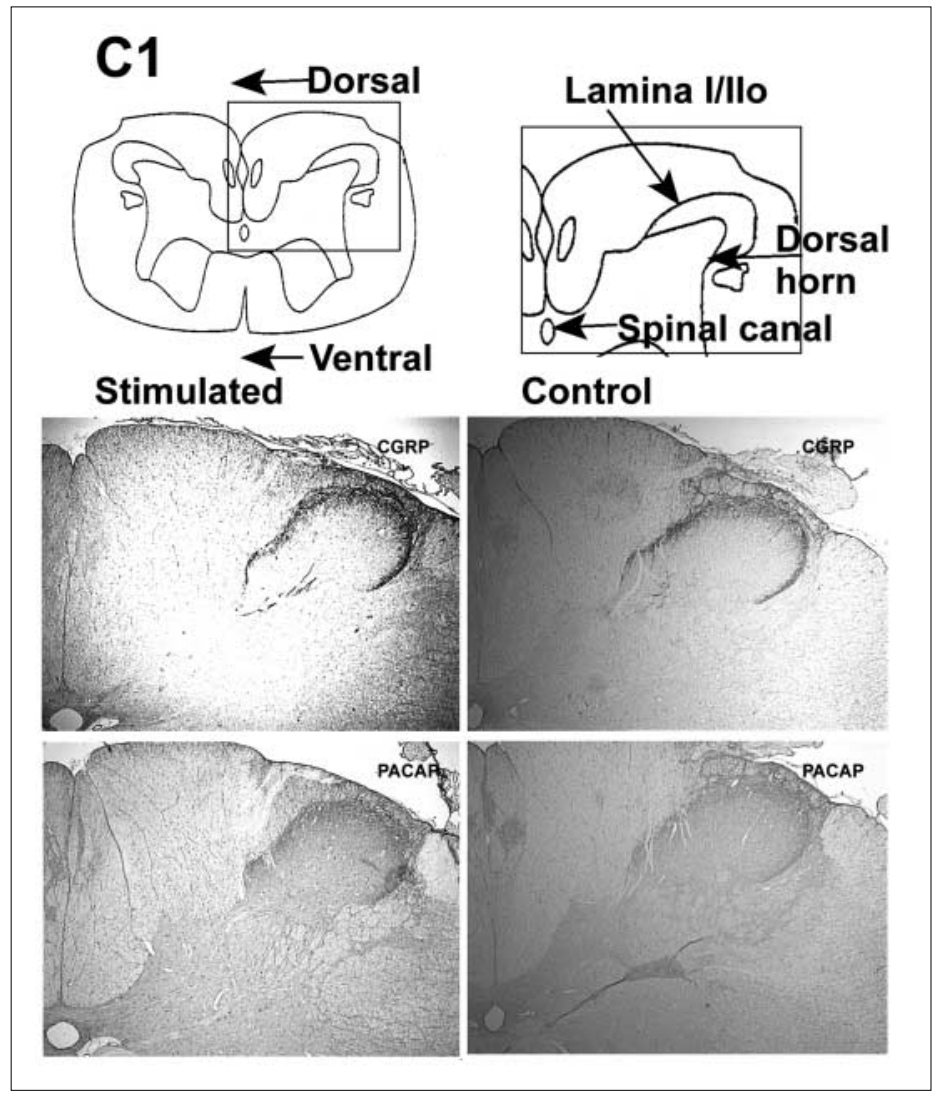

Fig. 2 The $\mathrm{C} 1$ level of cat cervical spinal cord. Organization of the area (top). Immunoreactivity of CGRP (middle) and PACAP (bottom)

Fig. 3 The C2 level of cat cervical spinal cord. Organization of the area (top). Immunoreactivity of CGRP (middle) and PACAP (bottom)

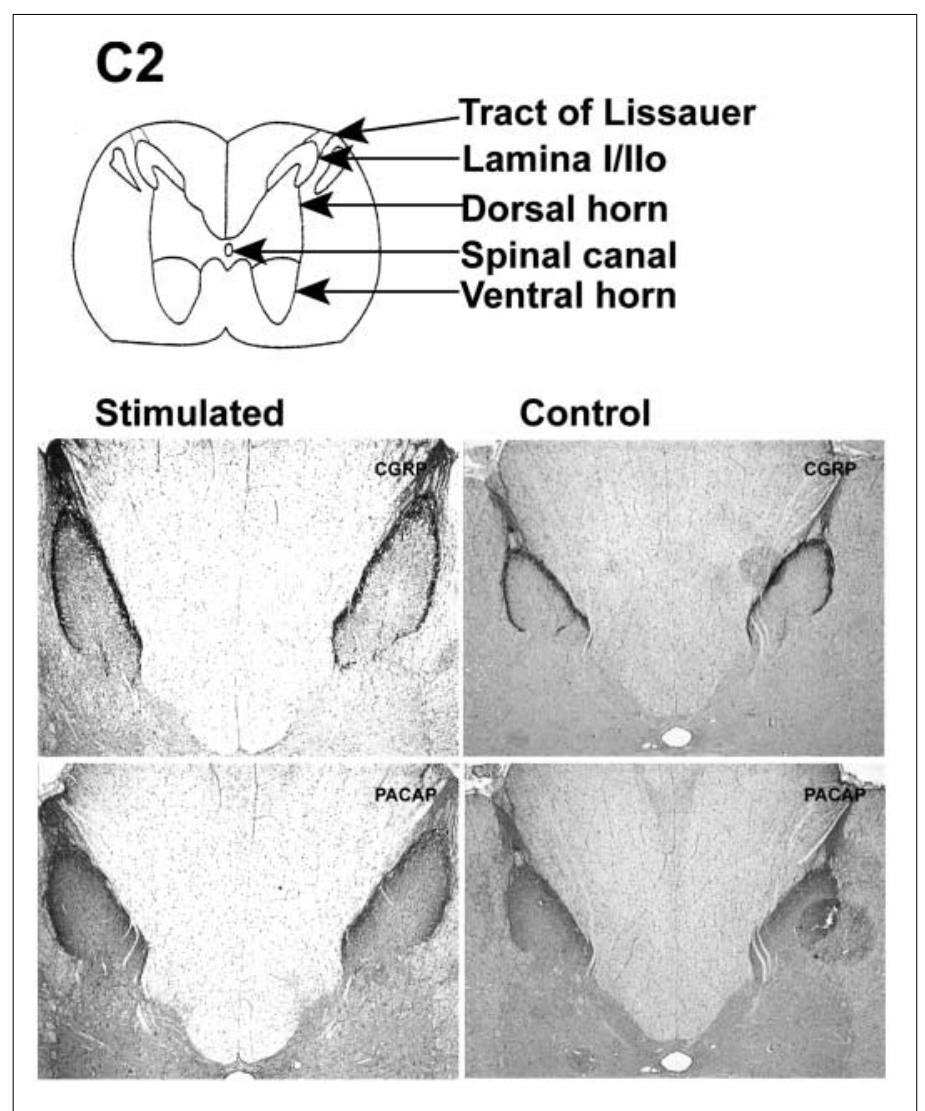


Fig. 4 The trigeminal nucleus caudalis (TNC) in the medulla oblongata in the cat. Immunoreactivity of SP (top), VIP (middle) and NOS (bottom)
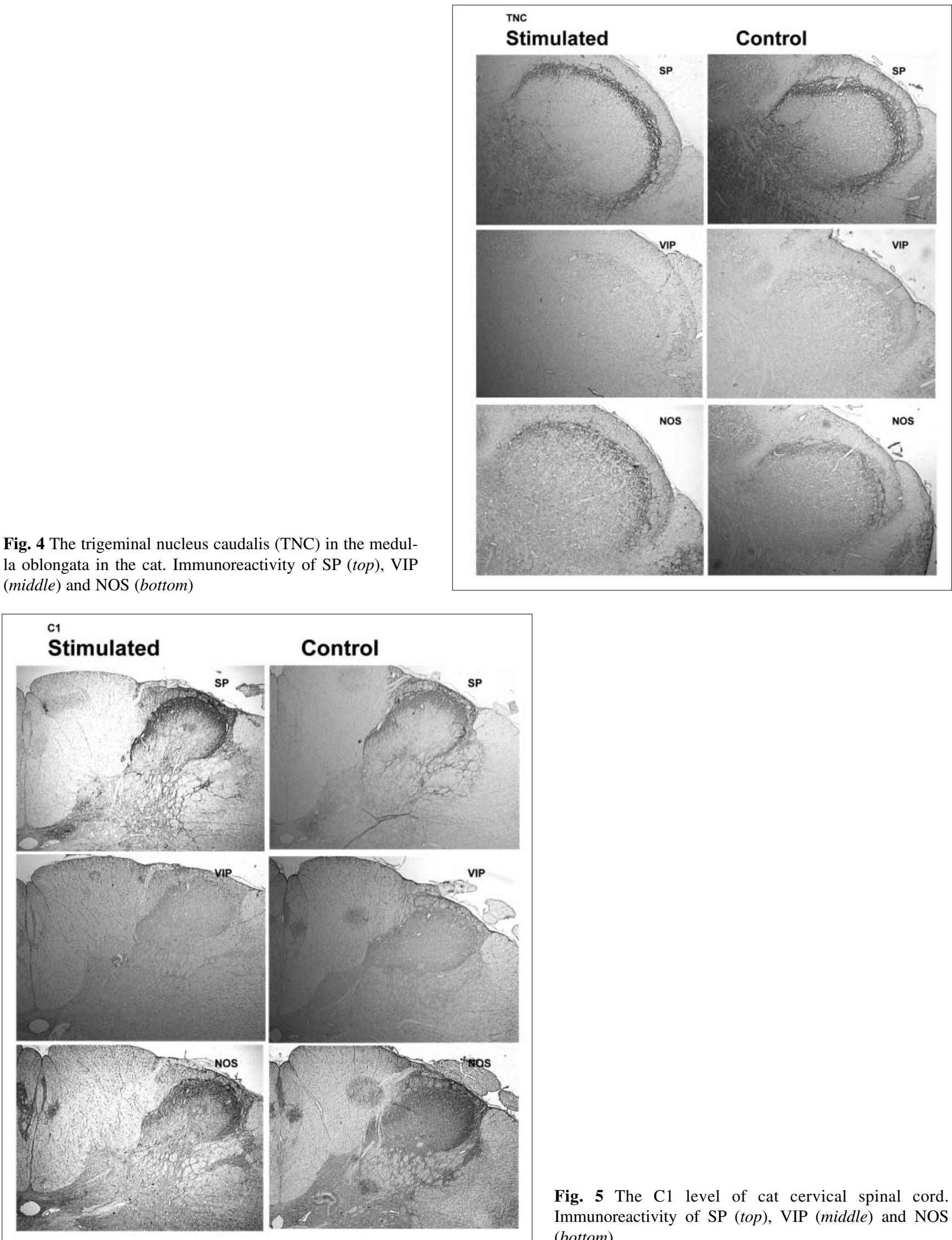

Fig. 5 The $\mathrm{C} 1$ level of cat cervical spinal cord. Immunoreactivity of SP (top), VIP (middle) and NOS (bottom). 


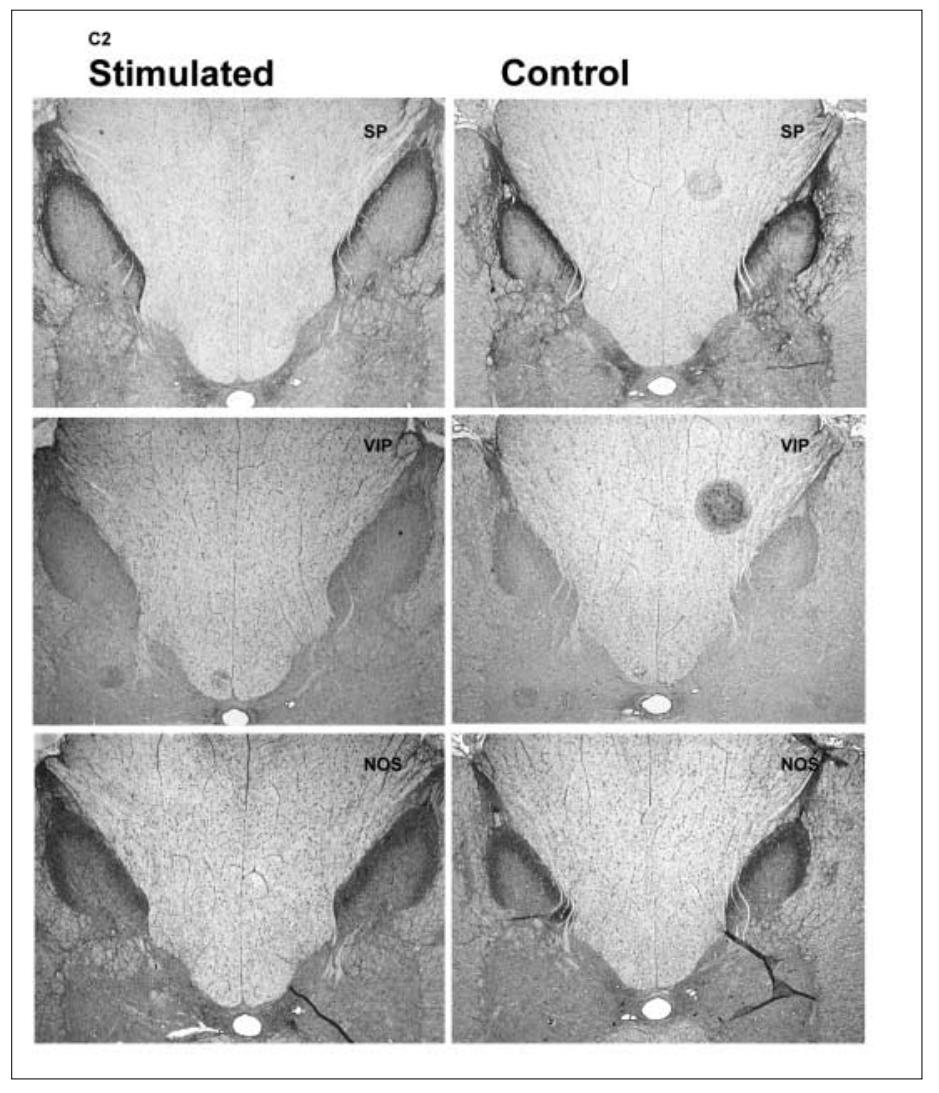

Fig. 6 The $\mathrm{C} 2$ level of cat cervical spinal cord. Immunoreactivity of SP (top), VIP (middle) and NOS (bottom). of Lissauer (Figs. 4, 6). There was no difference between the stimulated and control cats.

\section{Discussion}

This study shows that there is a rich supply of SP- and CGRP-positive fibers in the dorsal horn at Rexed lamina $\mathrm{I} / \mathrm{II}^{\circ}$ of TNC and at the $\mathrm{C} 1$ and $\mathrm{C} 2$ levels (Table 2). NOS and PACAP immunoreactivities were moderate in these areas while only occasional VIP-positive fibers were seen. This distribution of CGRP, SP and VIP immunoreactivity corresponds well with the pattern seen in earlier studies of other animals [17-20]. A similar pattern of NOS-positive nerve fibers has been described in the dorsal horn of the cat spinal cord [21-23]. However, PACAP immunoreactivity to our knowledge has not been studied in these brain stem areas before in the cat.

The origins of the fibers to these regions have been studied in numerous previous tracing studies, mainly from various cranial blood vessels to the ganglionic cells in the trigeminal ganglion in combination with co-localization of the various neurotransmitters located in the pathways [24-27]. The transganglionic tracing studies have shown that the perivascular sensory nerve fibers extend to the
TNC, C1 and C2 as examined in the present study [29]. To further study the origin of the positive fibers by unilateral denervation of the trigeminal ganglion has proven difficult [25-29]. We therefore chose to specifically stimulate the SSS, which results in specific activation of cells in TNC and in the cervical spinal cord [30]. Thus we could verify the location by a positive expression of the immediate early gene c-fos [30-32].

Table 2 Immunoreactivity towards neuropeptides and nitric oxide synthase (NOS) in cat brain and spinal cord regions. There were no differences between control cats and those stimulated in the superior sagittal sinus for $2 \mathrm{~h}$. Abbreviations are defined in Table 1

\begin{tabular}{lccc}
\hline & \multicolumn{3}{c}{ Immunostaining $^{\mathrm{a}}$} \\
\cline { 2 - 4 } Antigen & TNC & $\mathrm{C} 1$ & $\mathrm{C} 2$ \\
\hline CGRP & +++ & +++ & +++ \\
PACAP & ++ & ++ & ++ \\
SP & +++ & +++ & +++ \\
VIP & + & + & + \\
NOS & ++ & ++ & ++ \\
BSA $^{\text {b }}$ & - & - & - \\
\hline
\end{tabular}

a Arbitrary scale: - no staining, + faint, ++ moderate, +++ rich staining b Negative control 
Immunohistochemical analysis of the trigeminal ganglion revealed that nerve cell bodies are CGRP-, SP-, NOSand PACAP-positive in humans [33]. The cell bodies in the trigeminal ganglion also contain CGRP mRNA as shown by in situ hybridization [34]. In the present study, comparison of immunoreactivity of CGRP, PACAP, SP, VIP and NOS before and after stimulation of the SSS did not reveal any obvious difference between stimulated animals and controls. Low frequency stimulation for $2 \mathrm{~h}$ does not deplete the transmitter content in the cat, consistent with the fact that we can stimulate and record from neurons for a day at a time in electrophysiological studies. The absence of a difference in intensity of immunohistochemical staining of these neurotransmitters before and after stimulation may be explained by the fact that the DAB staining method is somewhat blunt for measuring subtle changes in concentrations of neurotransmitters; hence more sophisticated techniques (e.g. quantitative assays) might be required to unravel minor differences.

Another explanation may be that the changes in concentrations of these neurotransmitters were so brief after stimulation that the levels had already normalized at the time of sacrifice of the animals. Although the neuropeptides exist in the same regions as the immediate early gene c-fos, we cannot exclude the possibility that other neurotransmitters in these areas may be influenced by stimulation of the SSS. The current results are, however, perfectly consistent with the long time course of the typical migraine attack, in that there is no discernible transmitter depletion over a time frame in which headache may persist. The present observations of different immunoreactivies of neurotransmitters in TNC, C1 and C2 may help understand the neuronal messengers involved in primary headaches and may suggest ways to interact with these molecules in headache treatment. More specific knowledge about the function and importance of neurotransmitters in the TNC, $\mathrm{C} 1$ and $\mathrm{C} 2$ areas is needed. Stimulation of the trigeminovascular pathway and simultaneously blocking each of the neurotransmitters in vivo is one way that their functional roles may be further analyzed.

Acknowledgements This study was supported by grants from the Swedish Medical Research Council (no. 5958), The Wellcome Trust and The Migraine Trust. Peter J. Goadsby is a Wellcome Senior Research Fellow.

\section{References}

1. Goadsby PJ, Lipton RB, Ferrari MD (2002) Migraine-current understanding and treatment. N Engl J Med 346:257-270

2. Ray BS, Wolff HG (1940)

Experimental studies on headaches, pain sensitive structures of the head and their significance in headaches. Arch Surgery 41:813-856

3. Kandel ER, Schwartz JH, Jessell TM (1991) Principles of neural sciences. Elsevier, New York

4. Gulbenkian S, Uddman R, Edvinsson L (2001) Neuronal messengers in the human cerebral circulation. Peptides 22:995-1007

5. Goadsby PJ, Edvinsson L (1993) The trigeminovascular system and migraine: studies characterizing cerebrovascular and neuropeptide changes seen in humans and cats. Ann Neurol 33:48-56

6. Goadsby PJ, Edvinsson L, Ekman R (1988) Release of vasoactive peptides in the extracerebral circulation of humans and the cat during activation of the trigeminovascular system. Ann Neurol 23:193-196
7. Goadsby PJ, Edvinsson L, Ekman R (1990) Vasoactive peptide release in the extracerebral circulation of humans during migraine headache. Ann Neurol 28:183-187

8. Knyihar-Csillik E, Tajti J, Mohtasham S, Sari G, Vecsei L (1995) Electrical stimulation of the Gasserian ganglion induces structural alterations of calcitonin gene-related peptide-immunoreactive perivascular sensory nerve terminals in the rat cerebral dura mater: a possible model of migraine headache. Neurosci Lett 184:189-192

9. Juul R, Edvinsson L, Gisvold SE, Ekman R, Brubakk AO, Fredriksen TA (1990) Calcitonin gene-related peptideLI in subarachnoid haemorrhage in man. Signs of activation of the trigemino-cerebrovascular system? Br J Neurosurg 4:171-179

10. Juul R, Hara H, Gisvold SE, Brubakk AO, Fredriksen TA, Waldemar G, Schmidt JF, Ekman R, Edvinsson L (1995) Alterations in perivascular dilatory neuropeptides (CGRP, SP, VIP) in the external jugular vein and in the cerebrospinal fluid following subarachnoid haemorrhage in man. Acta Neurochir (Wien) 132:32-41
11. Goadsby PJ, Zagami AS, Lambert GA (1991) Neural processing of craniovascular pain: a synthesis of the central structures involved in migraine. Headache 31:365-371

12. Goadsby PJ, Zagami AS (1991) Stimulation of the superior sagittal sinus increases metabolic activity and blood flow in certain regions of the brainstem and upper cervical spinal cord of the cat. Brain 114(Pt 2):1001-1011

13. Hoskin KL, Kaube H, Goadsby PJ (1996) Central activation of the trigeminovascular pathway in the cat is inhibited by dihydroergotamine. A cFos and electrophysiological study. Brain 119(Pt 1):249-256

14. Hoskin KL, Kaube H, Goadsby PJ (1996) Sumatriptan can inhibit trigeminal afferents by an exclusively neural mechanism. Brain 119(Pt 5):1419-1428

15. Kaube H, Hoskin KL, Goadsby PJ (1993) Inhibition by sumatriptan of central trigeminal neurones only after blood-brain barrier disruption. $\mathrm{Br} \mathrm{J}$ Pharmacol 109:788-792 
16. Kaube H, Keay KA, Hoskin KL, Bandler R, Goadsby PJ (1993) Expression of c-fos-like immunoreactivity in the caudal medulla and upper cervical spinal cord following stimulation of the superior sagittal sinus in the cat. Brain Res 629:95-102

17. Fried K, Risling M, Arvidsson U, Paulie S (1990) Nerve growth factor receptor-like immunoreactivity in nerve fibers in the spinal and medullary dorsal horn of the adult monkey and cat: correlation with calcitonin gene-related peptide-like immunoreactivity. Brain Res 536:321-326

18. Hökfelt T, Ljungdahl Å, Terenius L, Elde R, Nilsson G (1977) Immunohistochemical analysis of the peptide pathways possibly related to pain and analgesia: enkephalin and substance P. Proc Natl Acad Sci U S A 74:3081-3085

19. Tashiro T, Ruda MA, Satoda T, Matsushima R, Mizuno N (1989) Convergence of serotonin-, enkephalin- and substance P-like immunoreactive afferent fibers onto cat medullary dorsal horn projection neurons: a triple immunocytochemical staining technique combined with the retrograde HRP-tracing method. Brain Res 491:360-365

20. Tessler A, Himes B, Krieger NR, Murray M, Goldberger ME (1985) Sciatic nerve transection produces death of dorsal root ganglion cells and reversible loss of substance $\mathrm{P}$ in spinal cord. Brain Res 332:209-218

21. Dun NJ, Dun SL, Wu SY, Forstermann U, Schmidt HH, Tseng LF (1993) Nitric oxide synthase immunoreactivity in the rat, mouse, cat and squirrel monkey spinal cord. Neuroscience 54:845-857
22. Pullen AH, Humphreys P, Baxter RG (1997) Comparative analysis of nitric oxide immunoreactivity in the sacral spinal cord of the cat, macaque and human. J Anat 191:161-175

23. Vizzard MA, Erdman SL, Roppolo JR, Förstermann U, de Groat WC (1994) Differential localization of neuronal nitric oxide immunoreactivity and NADPH-diaphorase activity in the cat spinal cord. Cell Tissue Res 278:299-309

24. Edvinsson L, Hara H, Uddman R (1989) Retrograde tracing of nerve fibers to the rat middle cerebral artery with true blue: colocalization with different peptides. J Cereb Blood Flow Metab 9:212-218

25. Hara H, Jansen I, Ekman R, Hamel E, MacKenzie ET, Uddman R, Edvinsson L (1989) Acetylcholine and vasoactive intestinal peptide in cerebral blood vessels: effect of extirpation of the sphenopalatine ganglion. J Cereb Blood Flow Metab 9:204-211

26. Uddman R, Edvinsson L, Hara $\mathrm{H}$ (1989) Axonal tracing of autonomic nerve fibers to the superficial temporal artery in the rat. Cell Tissue Res 256:559-565

27. Uddman R, Hara H, Edvinsson L (1989) Neuronal pathways to the rat middle meningeal artery revealed by retrograde tracing and immunocytochemistry. J Auton Nerv Syst 26:69-75

28. Arbab MA, Delgado T, Wiklund L, Svendgaard NA (1988) Brain stem terminations of the trigeminal and upper spinal ganglia innervation of the cerebrovascular system: WGA-HRP transganglionic study. J Cereb Blood Flow Metab 8:54-63
29. Uddman R, Edvinsson L, Ekman R, Kingman T, McCulloch J (1985) Innervation of the feline cerebral vasculature by nerve fibers containing calcitonin gene-related peptide: trigeminal origin and co-existence with substance P. Neurosci Lett 62:131-136

30. Hoskin KL, Goadsby PJ (1999) Exposure and isolation of the superior sagittal sinus elicits Fos in the trigeminal nucleus caudalis and dorsal horn of the cervical spinal cord: how long should you wait? Brain Res 824:133-135

31. Hoskin KL, Bulmer DC, Goadsby PJ (1999) Fos expression in the trigeminocervical complex of the cat after stimulation of the superior sagittal sinus is reduced by L-NAME. Neurosci Lett 266:173-176

32. Hoskin KL, Zagami AS, Goadsby PJ (1999) Stimulation of the middle meningeal artery leads to Fos expression in the trigeminocervical nucleus: a comparative study of monkey and cat. J Anat 194(Pt 4):579-588

33. Tajti J, Uddman R, Moller S, Sundler F, Edvinsson L (1999) Messenger molecules and receptor mRNA in the human trigeminal ganglion. J Auton Nerv Syst 76:176-183

34. Edvinsson L, Mulder H, Goadsby PJ, Uddman R (1998) Calcitonin generelated peptide and nitric oxide in the trigeminal ganglion: cerebral vasodilatation from trigeminal nerve stimulation involves mainly calcitonin generelated peptide. J Auton Nerv Syst 70:15-22 